\title{
Growth and contents of organic and inorganic solutes in amaranth under salt stress ${ }^{1}$
}

\author{
Renata Velasques Menezes ${ }^{2}$, André Dias de Azevedo Neto ${ }^{3}$, \\ Marcos de Oliveira Ribeiro ${ }^{2}$, Alide Mitsue Watanabe Cova ${ }^{2}$
}

\section{ABSTRACT}

Amaranthus cruentus L. is a forage species, with grains that exhibit excellent nutritional characteristics, being the 'BRS Alegria' the first cultivar recommended for cultivation in Brazil. This study aimed at evaluating the effect of salt stress on the growth and concentrations of organic and inorganic solutes in Amaranthus cruentus L. ('BRS Alegria' cultivar). Height, stem diameter, number of leaves, leaf, stem and root dry mass, leaf area, relative water content and membrane integrity percentage, as well as soluble carbohydrate, free amino acid, soluble protein, free proline, $\mathrm{Na}^{+}, \mathrm{Cl}^{-}$and $\mathrm{K}^{+}$contents, were evaluated in different plant organs. Salinity significantly reduced the biomass yield and leaf area from the treatment with $25 \mathrm{mM}$ of $\mathrm{NaCl}$, indicating that the 'BRS Alegria' cultivar is sensitive to salt stress. Soluble carbohydrates in the leaves decreased by $59 \%$, while the other organic solutes showed no substantial increases. These results, coupled with the reduction in the relative water content and membrane integrity, suggest a low ability of this cultivar to adjust osmotically under salt stress. The $\mathrm{K}^{+} / \mathrm{Na}^{+}$ ratio abruptly decreased in $25 \mathrm{mM}$ of $\mathrm{NaCl}$, suggesting an ionic imbalance, which may partially explain the salt-induced growth reduction.

KEYWORDS: Amaranthus cruentus L.; salinity; inorganic solutes; organic solutes; toxic ions.

\section{INTRODUCTION}

Salinity is considered one of the most important factors affecting agricultural productivity in arid and semiarid regions (Rady et al. 2013). Salt stress causes physiological disorders that reduce plant growth and yield due to the osmotic and ionic effects of salts. Osmotic stress is the first to affect plants in a saline environment, compromising their ability to absorb water, thereby reducing turgidity,

\section{RESUMO}

Crescimento e teores de solutos

orgânicos e inorgânicos em amaranto sob estresse salino

O Amaranthus cruentus L. é uma espécie forrageira, com grãos que possuem ótimas características nutricionais, sendo a cultivar 'BRS Alegria' a primeira recomendada para cultivo no Brasil. Objetivou-se avaliar o efeito do estresse salino no crescimento e concentrações de solutos orgânicos e inorgânicos em Amaranthus cruentus L. cv. 'BRS Alegria'. Foram avaliados a altura, diâmetro do caule, número de folhas, massa seca das folhas, caule e raízes, área foliar, teor relativo de água, porcentagem de integridade das membranas e teores de carboidratos solúveis, aminoácidos livres, proteínas solúveis, prolina livre, $\mathrm{Na}^{+}, \mathrm{Cl}^{-}$e $\mathrm{K}^{+}$, nos diferentes órgãos da planta. A salinidade reduziu fortemente a produção de biomassa e a área foliar a partir do tratamento com $25 \mathrm{mM}$ de $\mathrm{NaCl}$, indicando que a cultivar 'BRS Alegria' é sensível ao estresse salino. Os carboidratos solúveis nas folhas diminuíram 59 \%, enquanto os demais solutos orgânicos não apresentaram aumentos substanciais. Esses resultados, associados à diminuição do teor relativo de água e da integridade das membranas, sugerem uma baixa capacidade dessa cultivar para o ajustamento osmótico sob estresse salino. A razão $\mathrm{K}^{+} / \mathrm{Na}^{+}$reduziu-se abruptamente em $25 \mathrm{mM}$ de $\mathrm{NaCl}$, sugerindo desequilíbrio iônico, o que pode, ao menos em parte, explicar a redução de crescimento induzida pelo sal.

PALAVRAS-CHAVE: Amaranthus cruentus L.; salinidade; solutos inorgânicos; solutos orgânicos; íns tóxicos.

as well as cell elongation and division (Taiz \& Zeiger 2013).

$\mathrm{Na}^{+}$and $\mathrm{Cl}^{-}$, the main ions found in saline soils, are toxic to most glycophytes, since they cause nutrient disorders that affect the metabolic processes of plants (Marschner 2012). One of the mechanisms used by plants to minimize osmotic stress and ionic imbalance is osmotic adjustment, which results from the accumulation of inorganic ions and organic solutes with low molar mass, called compatible solutes (Slama et al. 2015).

1. Manuscript received in Jul./2016 and accepted for publication in Feb./2017 (http://dx.doi.org/10.1590/1983-40632016v4742580).

2. Universidade Federal do Recôncavo da Bahia, Centro de Ciências Agrárias e Ambientais, Cruz das Almas, BA, Brazil.

E-mails: renatavelasques.ufrb@gmail.com, marcosdeoliveira2@yahoo.com.br, alidewatanabe@yahoo.com.br.

3. Universidade Federal do Recôncavo da Bahia, Centro de Ciências Exatas e Tecnológicas, Cruz das Almas, BA, Brazil. E-mail: andre@ufrb.edu.br. 
Compatible organic solutes are metabolites that, when accumulated in cytosol, do not interfere with the biochemical reactions of cells (Bendaly et al. 2016) and protect enzymes, sub-cellular structures, biological membranes and proteins (Slama et al. 2015). The most widely compatible organic solutes in plants under salt stress are soluble carbohydrates, free amino acids, soluble proteins and free proline (Azevedo Neto et al. 2009, Sacramento et al. 2014).

Maintaining or changing ions and compatible organic solutes are the most common characteristics of salt-tolerant plants (Shannon \& Grieve 1999), and have been proposed as a physiological marker (Azevedo Neto et al. 2009).

Amaranthus cruentus L., popularly known as red amaranth, is among the most promising crops, due to the nutritional properties of its grains (Ferreira et al. 2007). In 1984, it was listed by the American National Research Council as one of the 36 alternative crops to reduce hunger in semiarid regions (USA 1989). It belongs to the Amaranthaceae family, which contains many salt-tolerant species, such as quinoa (Chenopodium quinoa Willd.) and saltbush (Atriplex nummularia). Quin et al. (2013) reported that $5 \mathrm{~g} \mathrm{~L}^{-1}$ of $\mathrm{NaCl}$ in the nutrient solution do not affect the Amaranthus cruentus L. yield, as well as its pigment content, photosynthesis, transpiration rate, stomatal conductance or antioxidant enzyme activities.

The present study aimed at assessing the degree of tolerance to increase salinity levels by analyzing the growth and accumulation of organic and inorganic solutes in different seedling organs of the Amaranthus cruentus L. 'BRS Alegria' cultivar, grown in a hydroponic system under salt stress.

\section{MATERIAL AND METHODS}

The experiment was conducted in a protected environment at the Universidade Federal do Recôncavo da Bahia, between September and October 2014. The 'BRS Alegria' cultivar was used because it was the first one recommended in Brazil and due to its uniform agronomic characteristics (Spehar 2003). The experimental design was completely randomized, with five levels of $\mathrm{NaCl}$ in the nutrient solution and four repetitions.

The seeds were germinated in $200 \mathrm{~mL}$ plastic pots containing washed sand and irrigated daily with tap water. After germination, the seedlings were irrigated with a nutrient solution at half ionic strength (Furlani 1998). Plants were selected at 18 days after germination and the roots were washed and then transferred to trays containing $12 \mathrm{~L}$ of the same nutrient solution, in a floating hydroponic solution, with aeration. The seedlings remained under these conditions for 3 days to acclimate them. Saline treatments were then applied, as it follows: $0 \mathrm{mM}$, $25 \mathrm{mM}, 50 \mathrm{mM}, 75 \mathrm{mM}$ and $100 \mathrm{mM}$ of $\mathrm{NaCl} . \mathrm{NaCl}$ was added gradually $\left(25 \mathrm{mM}\right.$ of $\mathrm{NaCl}$ day $\left.^{-1}\right)$ to avoid osmotic shock.

The volume of nutrient solution was filled up daily with water and the solution was changed every 7 days. The $\mathrm{pH}$ was assessed every 2 days and, when necessary, adjusted to $6.0 \pm 0.5$, with the use of $\mathrm{NaOH}$ or $\mathrm{HCl}$. The system was maintained under intermittent aeration for 15 min every hour, using an air compressor coupled with a timer.

The harvest occurred at 22 days after the onset of salt treatments. Plant height, stem diameter, leaf fresh mass and leaf area were measured. Plant height was measured on the central stem, from the base to the last leaf, and the stem diameter around $5 \mathrm{~cm}$ above the root insertion. Leaf area was determined using a WinDIAS W-C110-PC image analysis system (Delta-T Devices Ltd, Cambridge, UK). The plants were subdivided into leaves, stem and roots and transferred to a forced air oven at $65^{\circ} \mathrm{C}$, for $72 \mathrm{~h}$, to determine leaf, stem and root dry mass, on an analytical scale. These data were used to calculate the total dry mass and ratio between shoot dry mass and root dry mass.

Assessments of absolute integrity percentage (AIP) of cell membranes and relative water content (RWC) were conducted in the same leaves used in pigment analysis, according to the methodologies described by Pimentel et al. (2002) and Barr \& Watherley (1962), respectively:

$$
\begin{aligned}
& \operatorname{AIP}(\%)=100-(\mathrm{FC} \times 100 / \mathrm{TC}) \\
& \operatorname{RWC}(\%)=[(\mathrm{DM}-\mathrm{FM}) /(\mathrm{DM}-\mathrm{TM})] \times 100
\end{aligned}
$$

where FC is the free conductivity; TC the total conductivity; DM the leaf disc dry mass; FM the fresh mass; and TM the turgid mass.

To determine the $\mathrm{Na}^{+}, \mathrm{K}^{+}$and $\mathrm{Cl}^{-}$contents, the extracts were prepared as described by Jones (2001), with slight changes. Test tubes were added with $100 \mathrm{mg}$ of ground dry matter and $10 \mathrm{~mL}$ of deionized water. The tubes were heated to $80{ }^{\circ} \mathrm{C}$ in water bath for $1 \mathrm{~h}$. Next, the extracts were centrifuged at $5,000 \times \mathrm{g}$ and the supernatant was filtered in 
quantitative filter paper. The $\mathrm{Na}^{+}$and $\mathrm{K}^{+}$contents were determined by flame photometry (Faithfull 2002) and FC- by spectrophotometry (Jones 2001).

During the collection process, samples of leaves and roots were frozen, lyophilized, ground and stored in a freezer, to determine organic solute contents. The raw extract was obtained by grinding $200 \mathrm{mg}$ of lyophilized leaf and root tissue in a mortar with $6 \mathrm{~mL}$ of $0.1 \mathrm{M}$ potassium phosphate buffer, $\mathrm{pH}$ 7.0 , containing $0.1 \mathrm{mM}$ of EDTA. The extract was filtered through muslin and centrifuged at $12,000 \times \mathrm{g}$, for $15 \mathrm{~min}$. The supernatant was used to determine the soluble carbohydrate, free amino acid, soluble protein and free proline levels.

The soluble carbohydrate content was determined by spectrophotometry at $490 \mathrm{~nm}$, applying the phenol-sulfuric acid method and D-(+)glucose as standard (Dubois et al. 1956). Free proline was established by spectrophotometry at $520 \mathrm{~nm}$, using ninhydrin as specific reagent and pure proline as standard (Bates et al. 1973). Total free amino acids were evaluated by spectrophotometry at $570 \mathrm{~nm}$, using the ninhydrin method and pure L-leucine as standard (Yemm \& Cocking 1955). Soluble proteins were determined by spectrophotometry at $595 \mathrm{~nm}$, applying the dye-binding method and bovine serum albumin as standard (Bradford 1976).

The data were submitted to analysis of variance and regression using the Sisvar 4.6 software (Ferreira 2011). The models were selected as a function of their biological significance, F-test significance and coefficient of determination $\left(\mathrm{R}^{2}\right)$.

\section{RESULTS AND DISCUSSION}

The changes in plant height, stem diameter, biomass yield, shoot/root ratio and leaf area of the Amaranthus cruentus L. 'BRS Alegria' cultivar are presented in Figure 1. The increase in $\mathrm{NaCl}$ doses in the nutrient solution reduced plant height according to a quadratic model (Figure 1A). The plants had a minimum height of $17.90 \mathrm{~cm}$ with $84.40 \mathrm{mM}$ of $\mathrm{NaCl}$. Salinity linearly decreased stem diameter, accounting for a $50 \%$ decline in the treatment with $100 \mathrm{mM}$ of $\mathrm{NaCl}$ (Figure 1B). These reductions may be associated with the decreased osmotic potential of the solution, which acts negatively on physiological processes, reducing water absorption by the roots, inhibiting meristematic activity and cell elongation and division (Ayers \& Westcot 1999).
Salt stress also decreased the leaf area and dry mass yield of the different organs. The data were adjusted to the logistic model, with a sharp reduction at $25 \mathrm{mM}$ of $\mathrm{NaCl}$ and a tendency to stabilization at subsequent concentrations. As such, the regression equations indicate that the treatment with $100 \mathrm{mM}$ of $\mathrm{NaCl}$ decreased the leaf dry mass, stem dry mass, root dry mass, total dry mass and leaf area by $73 \%, 74 \%, 49 \%, 70 \%$ and $74 \%$, respectively, if compared to the controls (Figures 1C, 1D, 1E, 1F and $1 \mathrm{H})$. The equations also indicate that the dry mass yield and leaf area declined by $50 \%$ at an average concentration of $32 \mathrm{mM}$ of $\mathrm{NaCl}$.

The salt-induced growth decrease is an effect commonly observed in several plant species (Cunha et al. 2013, Matos et al. 2013, Sacramento et al. 2014) and is frequently related to nutritional imbalances (Schossler et al. 2012). Odjegba \& Chukwunwike (2012) also reported growth inhibition in Amaranthus hybridus under salt stress, suggesting that the species is sensitive.

The decline in biomass induced by salinity may be explained by two subsequent events. The first is the osmotic effect, which restricts water absorption and transport. This restriction leads to the second event, which is triggered by a sequence of reactions mediated by hormones that reduce stomatal opening, $\mathrm{CO}_{2}$ photosynthetic assimilation (Silveira et al. 2010, Odjegba \& Chukwunwike 2012) and, consequently, dry mass yield. Another factor is the deviation of energy from growth to maintenance, i.e., a reduction of dry mass may result from the metabolic cost of energy associated with acclimation to salinity and a reduction in carbon gains (Atkin \& Macherel 2009).

Many authors use growth variables to select plants tolerant to salt stress (Singh \& Sarkar 2014, Bendaly et al. 2016). According to Munns \& Tester (2008), the salinity limit for a significant reduction in shoot growth in most plants is $40 \mathrm{mM}$ of $\mathrm{NaCl}$.

The decrease in leaf area as a salinity tolerance mechanism is controversial. While some authors consider that the transitory decline in the surface area is a tolerance mechanism that enables water conservation (Matos 2013), others believe that a more pronounced reduction in leaf area is a characteristic of sensitivity, since it causes a decline in the photosynthetic area, gas exchanges and, consequently, biomass yield (Costa et al. 2003). Given that the biomass yield and leaf area of the 'BRS Alegria' cultivar fell $50 \%$ at a concentration 


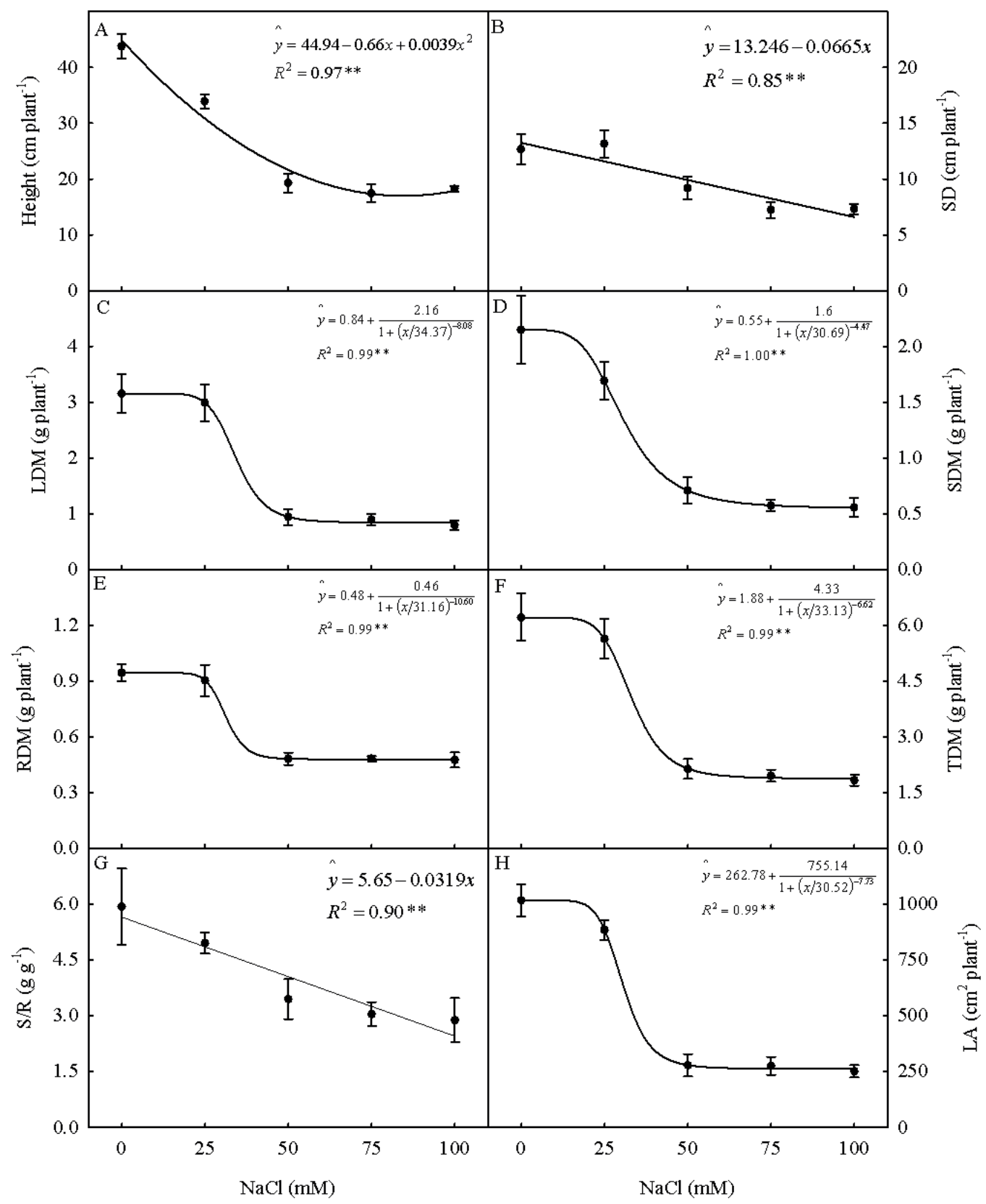

Figure 1. Height (A), stem diameter (B), leaf dry mass (C), stem dry mass (D), root dry mass (E), total dry mass (F), shoot/root ratio $(\mathrm{G})$ and leaf area $(\mathrm{H})$ of Amaranthus cruentus L., at 30 days after growing in a nutrient solution containing increasing levels of $\mathrm{NaCl}$. Points represent the averages of four replicates, with their respective standard deviations.

of $32 \mathrm{mM}$ of $\mathrm{NaCl}$, the data indicate that this cultivar is salt sensitive.

For the shoot/root ratio, a linear adjustment was observed, with a $56 \%$ reduction at $100 \mathrm{mM}$ of $\mathrm{NaCl}$, in relation to the control plants (Figure $1 \mathrm{G}$ ). This result indicates that the effect of salinity was more pronounced in the shoot than in the root, suggesting that this organ is more tolerant to salt stress.
Similar results were obtained by Azevedo Neto \& Tabosa (2000), with maize plants under salt stress. These authors reported that the roots seem to better withstand salinity than the shoots, a phenomenon that could be associated with faster osmotic adjustment and slower loss of turgor in the roots, if compared to the shoots, in addition to providing a better protection against oxidative stress (Abreu et al. 2008). 
Relative water content and absolute integrity percentage declined linearly with salinity. Thus, at $100 \mathrm{mM}$ of $\mathrm{NaCl}$, the estimated reductions in these variables were $19 \%$ and $18 \%$, respectively, in relation to the controls (Figures 2A and 2B). Similar results were reported for Amaranthus hybridus under salt stress (Odjegba \& Chukwunwike 2012). The same authors suggested that the response was the result of lower water potential, which directly affected the absorption of water by roots.

The decline in the relative water content observed in this study indicates a loss of turgor, which results in less water available for cell expansion. Moreover, the decrease in the absolute integrity percentage suggests a greater electrolyte leakage. As such, the salt-induced relative water content decrease may also have occurred due to the reduction in the membrane integrity (Pandey \& Gautam 2009).

The soluble carbohydrate content in leaves exhibited a quadratic adjustment, declining from $507.96 \mathrm{mmol} \mathrm{g}^{-1}$ of dry mass in the control to $205.46 \mathrm{mmol} \mathrm{g}^{-1}$ of dry mass at $83.39 \mathrm{mM}$ of $\mathrm{NaCl}$ (Figure 3A). In roots, carbohydrates increased linearly from $98.95 \mathrm{mmol} \mathrm{g}^{-1}$ of dry mass in the control to $167.65 \mathrm{mmol} \mathrm{g}^{-1}$ of dry mass at $100 \mathrm{mM}$ of $\mathrm{NaCl}$ (Figure 3B). In contrast with carbohydrates, the leaf amino acid content showed a slight increase from the control treatment (100.99 $\mathrm{mmol} \mathrm{g}^{-1}$ of dry mass) to $100 \mathrm{mM}$ of $\mathrm{NaCl}\left(136.00 \mathrm{mmol} \mathrm{g}^{-1}\right.$ of dry mass) (Figure $3 \mathrm{C}$ ). In roots, amino acids did not vary with a rise in salinity in the nutrient solution (Figure 3D).

Salinity linearly decreased the soluble protein content of leaves and roots (Figures 3E and 3F). As such, at $100 \mathrm{mM}$ of $\mathrm{NaCl}$, the reductions observed in relation to the control were $11 \%$ and $38 \%$, respectively. In leaves, free proline exhibited an increasing linear behavior, with a maximum content of $4.22 \mathrm{mmol} \mathrm{g}^{-1}$ of dry mass at $100 \mathrm{mM}$ of $\mathrm{NaCl}$ (Figure $3 \mathrm{G}$ ). For roots, the maximum proline content was $4.18 \mathrm{mmol} \mathrm{g}^{-1}$ of dry mass at $35.21 \mathrm{mM}$ of $\mathrm{NaCl}$ (Figure 3H).

Among the organic solutes, soluble carbohydrates and free amino acids are the primary compounds involved in osmotic adjustment (Azevedo Neto et al. 2010). Considering the pronounced reduction in the soluble carbohydrate content in the leaves and the slight increase in free amino acids and proline, the data suggest a lower tissue hydration and the absence of osmotic adjustment from the accumulation of organic solutes. This may partially explain the salt-induced growth decrease in Amaranthus cruentus L., given that cell growth is dependent on turgidity and is highly sensitive to water deficiency (Taiz \& Zeigher 2013).

The $\mathrm{Cl}^{-}$and $\mathrm{Na}^{+}$contents in the plant organs increased linearly with a rise of $\mathrm{NaCl}$ in the nutrient solution (Figure 4). It can also be observed that, at $100 \mathrm{mM}$ of $\mathrm{NaCl}$, the estimated contents of $\mathrm{Cl}^{-}$and $\mathrm{Na}^{+}$were $0.91 \mathrm{mmol} \mathrm{g}^{-1}$ and $1.26 \mathrm{mmol} \mathrm{g}^{-1}$ of dry mass in the leaves, $1.26 \mathrm{mmol} \mathrm{g}^{-1}$ and $2.43 \mathrm{mmol} \mathrm{g}^{-1}$ of dry mass in the stem and $0.64 \mathrm{mmol} \mathrm{g}^{-1}$ and $2.38 \mathrm{mmol} \mathrm{g}^{-1}$ of dry mass in the roots, respectively (Figures 4A, 4B, $4 \mathrm{C}, 4 \mathrm{D}, 4 \mathrm{E}$ and 4F). Costa et al. (2008) also observed that salinity increased the $\mathrm{Cl}^{-}$and $\mathrm{Na}^{+}$contents in different parts of Amaranthus ssp.

In salt stress, ionic toxicity is established by the accumulation of $\mathrm{Na}^{+}$and $\mathrm{Cl}^{-}$in plant tissues, which causes ionic imbalance and stress, impairing the plant development (Cavalcante et al. 2010). According to Munns \& Tester (2008), the ability to restrict

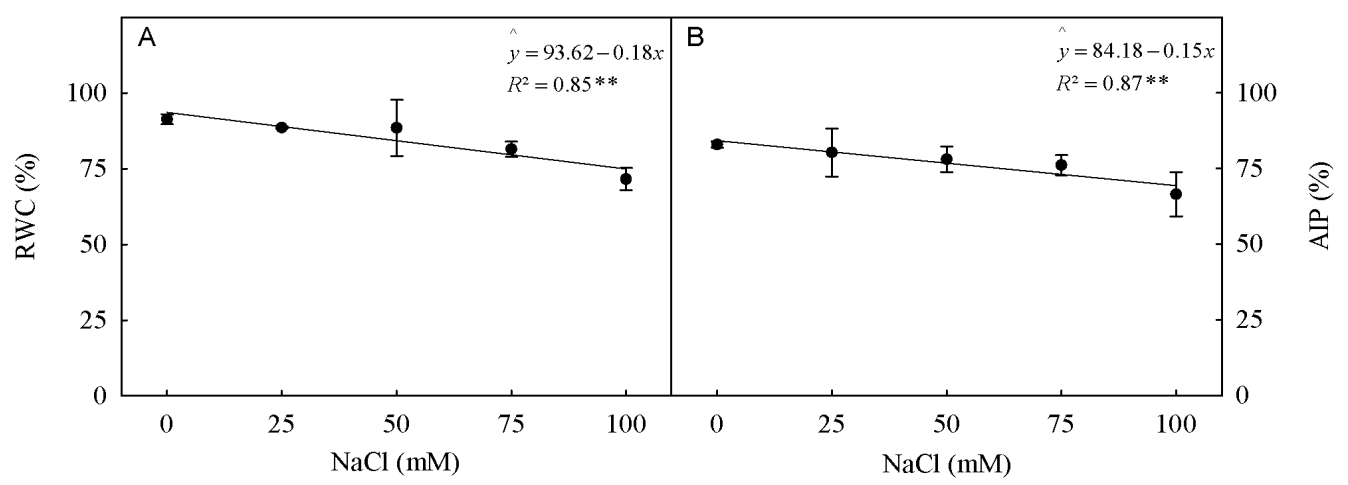

Figure 2. Relative water content (A) and absolute integrity percentage (B) of cell membranes in Amaranthus cruentus L., at 30 days after growing in a nutrient solution containing increasing levels of $\mathrm{NaCl}$. Points represent the averages of four replicates, with their respective standard deviations. 


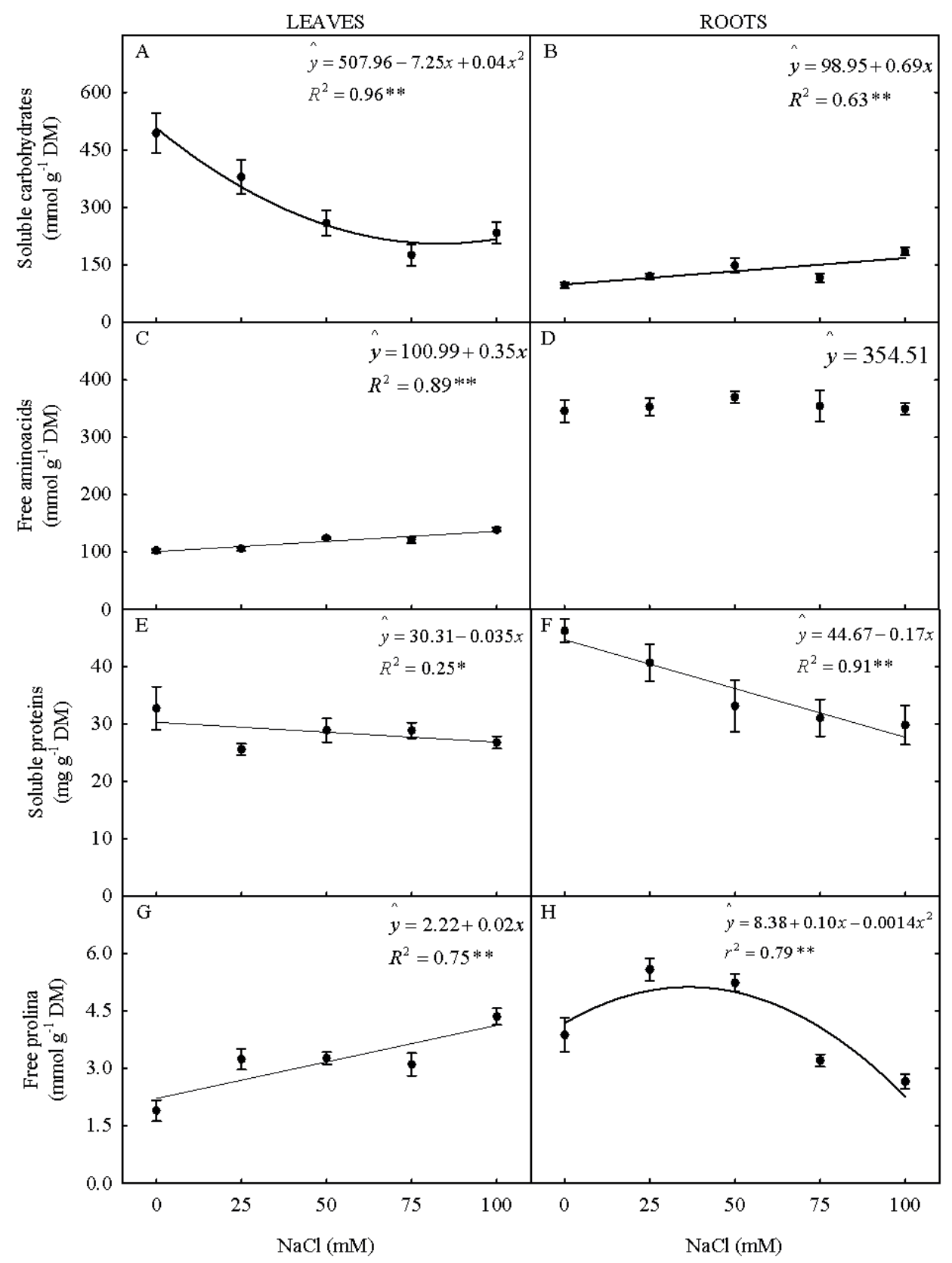

Figure 3. Soluble carbohydrates, free amino acids, soluble proteins and free proline contents in leaves (A, C, E and G) and roots (B, D, F and H) of Amaranthus cruentus L., at 30 days after growing in a nutrient solution containing increasing levels of $\mathrm{NaCl}$. Points represent the average of four replicates, with their respective standard deviations.

transport and toxic ion accumulation in leaves is the most important characteristic for salinity tolerance. Our results show that the 'BRS Alegria' cultivar did not restrict the $\mathrm{Na}^{+}$and $\mathrm{Cl}^{-}$transport to the shoot, indicating that the sensitivity of the cultivar to salt stress may be related to the high levels of these ions in leaves. Although the accumulation of $\mathrm{Na}^{+}$and $\mathrm{Cl}^{-}$plays an important role in osmotic adjustment (Rodrigues et al. 2014), this was not shown for
Amaranthus cruentus L., given the decrease in the relative water content with a rise in salinity.

In the leaves of Amaranthus cruentus L., the $\mathrm{K}^{+}$content was adjusted to a quadratic model, with a maximum estimated content of $0.97 \mathrm{mmol} \mathrm{g}^{-1}$ of dry mass at $50 \mathrm{mM}$ of $\mathrm{NaCl}$ (Figure $4 \mathrm{G}$ ). In the stems and roots, $\mathrm{K}^{+}$declined linearly as a function of the increase of $\mathrm{NaCl}$ in the nutrient solution (Figures $4 \mathrm{H}$ and $4 \mathrm{I}$ ). As such, at $100 \mathrm{mM}$ of $\mathrm{NaCl}$, the estimated 
$\mathrm{K}^{+}$contents in the stem and roots were $62 \%$ and $51 \%$ lower than in the controls, respectively. $\mathrm{K}^{+}$ plays an important role in regulating the osmotic potential of plant cells and activating some enzymes involved in respiration and photosynthesis (Taiz \& Zeiger 2013). Thus, the decreased content of this ion has been considered one of the responsible for reducing growth in a number of plant species under salt stress, since it directly affects stomatal opening and closing, as well as the regulation of water and osmotic potential of plant cells (Cunha et al. 2013, Taiz \& Zeiger 2013).

The $\mathrm{K}^{+} / \mathrm{Na}^{+}$ratio declines according to a hyperbolic model in all parts of the plant. In the

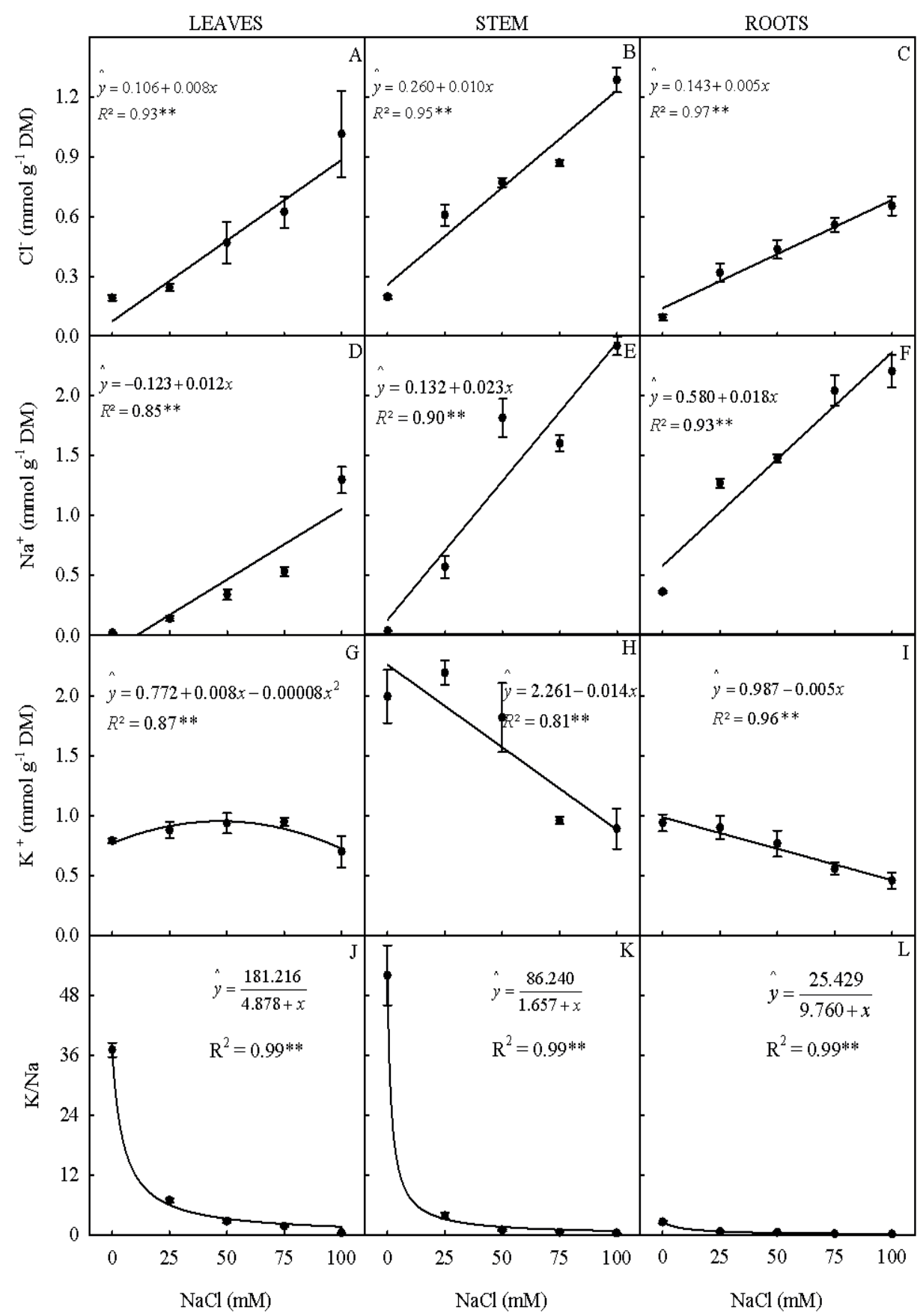

Figure 4. Sodium, chloride and potassium contents and potassium/sodium ratio in leaves (A, D, G, J), stems (B, E, H, K) and roots (C, F, I, L) of Amaranthus cruentus L., at 30 days after growing in a nutrient solution containing increasing levels of $\mathrm{NaCl}$. Points represent the averages of four replicates, with their respective standard deviations. 
treatment at $25 \mathrm{mM}$ of $\mathrm{NaCl}$, the $\mathrm{K}^{+} / \mathrm{Na}^{+}$ratio decreased sharply in the leaves $(84 \%)$, stem (94\%) and roots ( $72 \%$ ), if compared to the control (Figures 4J, 4K and 4L). In a saline medium, the $\mathrm{K}^{+}$absorption may be lower, due to the antagonistic relationship between $\mathrm{Na}^{+}$and $\mathrm{K}^{+}$ions. As such, an increase in the $\mathrm{Na}^{+}$levels is generally followed by a decline in the $\mathrm{K}^{+}$content (Greenway \& Munns 1980), what corroborates the results obtained in this study.

Bosco et al. (2009) reported that the $\mathrm{K}^{+} / \mathrm{Na}^{+}$ ratio is an important variable in the nutritional study of plants under saline conditions, and Azevedo Neto \& Tabosa (2000) stated that this ratio is strongly related to the tolerance of plant species to salinity. The same authors found that, under salt stress, an ionic absorption imbalance results from the lower selectivity between $\mathrm{Na}^{+}$and $\mathrm{K}^{+}$ions in the roots, due to the loss of membrane integrity.

In glycophytes, the $\mathrm{K}^{+} / \mathrm{Na}^{+}$ratio must be higher than 1.0, to maintain ionic hemostasis and metabolic efficiency (Greenway \& Munns 1980). As such, the results of this study suggest that the ionic imbalance may partially explain the reduction in the biomass yield of the 'BRS Alegria' cultivar induced by salinity. This hypothesis is supported by the fact that both the $\mathrm{K}^{+} / \mathrm{Na}^{+}$ratio and biomass yield declined sharply with $\mathrm{NaCl}$ at concentrations higher than $25 \mathrm{mM}$.

\section{CONCLUSIONS}

1. The biomass yield and leaf area indicate that the Amaranthus cruentus L. 'BRS Alegria' cultivar is sensitive to salt stress;

2. The organic solute levels, relative water content and membrane integrity percentage show that the inefficiency of osmotic adjustment is an important factor for the salt sensitivity of the 'BRS Alegria' cultivar;

3. Salinity changes the ionic homeostasis of the 'BRS Alegria' cultivar, what could partially explain the salt-induced decline in growth.

\section{REFERENCES}

ABREU, C. E. B. et al. Physiological and biochemical changes occurring in dwarf cashew seedlings subjected to salt stress. Brazilian Journal of Plant Physiology, v. 20, n. 2, p. 105-118, 2008.
ATKIN, O. K.; MACHEREL, D. The crucial role of plant mitochondria in orchestrating drought tolerance. Annals of Botany, v. 103, n. 4, p. 581-597, 2009.

AYERS, R. S.; WESTCOT, D. W. A qualidade da água na agricultura. 2. ed. Campina Grande: UFPB, 1999.

AZEVEDO NETO, A. D. et al. Physiological and biochemical responses of peanut genotypes to water deficit. Journal of Plant Interactions, v. 5, n. 1, p. 1-10, 2010.

AZEVEDO NETO, A. D.; PRISCO, J. T.; GOMESFILHO, E. Changes in soluble amino-N, soluble proteins and free amino acids in leaves and roots of salt-stressed maize genotypes. Journal of Plant Interactions, v. 4, n. 1, p. 137-144, 2009.

AZEVEDO NETO, A. D.; TABOSA, J. N. Estresse salino em plântulas de milho. Parte I: análise do crescimento. Revista Brasileira de Engenharia Agrícola e Ambiental, v. 4, n. 2, p. 159-164, 2000.

BARR, H. D.; WEATHERLEY, P. E. A re-examination of the relative turgidity technique for estimating water deficit in leaves. Australian Journal of Biology Science, v. 15, n. 3, p. 413-428, 1962.

BATES, L. S.; WALDREN, R. P.; TEARE, I. D. Rapid determination of free proline for water-stress studies. Plant and Soil, v. 39, n. 1, p. 205-207, 1973.

BENDALY, A. et al. Physiological and leaf metabolome changes in the xerohalophyte species Atriplex halimus induced by salinity. Plant Physiology and Biochemistry, v. 103, n. 1, p. 208-218, 2016.

BOSCO, M. R. O. et al. Influência do estresse salino na composição mineral da berinjela. Revista Ciência Agronômica, v. 40, n. 2, p. 157-164, 2009.

BRADFORD, M. M. A rapid and sensitive method for the quantification of microgram quantities of protein utilizing the principle of protein-dye binding. Analytical Biochemistry, v. 72, n. 1-2, p. 248-254, 1976.

CAVALCANTE, L. F. et al. Fontes e níveis da salinidade da água na formação de mudas de mamoeiro cv. Sunrise solo. Semina: Ciências Agrárias, v. 31, n. 1, p. 1281-1290, 2010.

COSTA, P. H. A. et al.Crescimento e níveis de solutos orgânicos e inorgânicos em cultivares de Vigna unguiculata submetidos à salinidade. Revista Brasileira de Botânica, v. 26, n. 3, p. 289-297, 2003.

COSTA, D. M. A. et al. Conteúdo de N, $\mathrm{P}, \mathrm{K}^{+}, \mathrm{Ca}^{2+} \mathrm{e}$ $\mathrm{Mg}^{2+}$ no amaranto (Amaranthus spp.) sob estresse salino e cobertura morta. Revista Ciência Agronômica, v. 39, n. 2, p. 209-216, 2008.

CUNHA, P. C. et al. Crescimento, síntese de solutos orgânicos e equilíbrio iônico de plântulas de pinhão- 
manso sob estresse salino. Revista Caatinga, v. 26, n. 3, p. 46-52, 2013.

DUBOIS, M. et al. Colorimetric method for determination of sugars and related substances. Analytical Chemistry, v. 28 , n. 3, p. 350-356, 1956.

FAITHFULL, N. T. Methods in agricultural chemical analysis: a practical handbook. Wallingford: CABI Publishing, 2002.

FERREIRA, D. F. Sisvar: a computer statistical analysis system. Ciência \& Agrotecnologia, v. 35, n. 6, p. 10391042, 2011.

FERREIRA, T. A. P. C.; MATIAS, A. C. G.; AREAAS, J. A. $\mathrm{G}$. Características nutricionais e funcionais do amaranto (Amaranthus spp.). Nutrire, v. 32, n. 2, p. 91-116, 2007.

FURLANI, P. R. Instrução para o cultivo de hortaliça de folha pela técnica de hidroponia-NFT. Campinas: Instituto Agronômico, 1998.

GREENWAY, H.; MUNNS, R. Mechanisms of salt tolerance in nonhalophytes. Annual Review of Plant Physiology, v. 31, n. 1, p. 149-190, 1980.

JONES, J. B. Laboratory guide for conducting soil tests and plant analysis. Boca Raton: CRC Press, 2001.

MARSCHNER, P. Marschner's mineral nutrition of higher plants. 3. ed. London: Academic Press, 2012.

MATOS, F. S. et al. Desenvolvimento de mudas de pinhãomanso irrigadas com água salina. Revista Brasileira de Ciência do Solo, v. 37, n. 4, p. 947-954, 2013.

MUNNS, R.; TESTER, M. Mechanisms of salinity tolerance. Annual Review of Plant Biology, v. 59, n. 1, p. 651-681, 2008.

ODJEGBA, V. J.; CHUKWUNWIKE, I. C. Physiological responses of Amaranthus hybridus L. under salinity stress. Indian Journal of Innovations and Developments, v. 1, n. 10, p. 742-748, 2012.

PANDEY, S. N.; GAUTAM, S. Effect of nickel stress on growth and physiological responses of Trigonella foenumgraecum L. plants grown in Gomati upland alluvial soil of Lucknow. Indian Botanical Society, v. 88, n. 1, p. 1-3, 2009.

PIMENTEL, C. et al. Tolerância protoplasmática foliar à seca, em dois genótipos de caupi cultivados em campo. Revista de Ciências da Vida, v. 22, n. 1, p. 7-14, 2002.

QUIN, L. et al. Effect of salt stress on growth and physiology in amaranth and lettuce: implications for bioregenerative life support system. Advances in Space Research, v. 51, n. 3, p. 476-482, 2013.
RADY, M. M.; BHAVYA, V. C.; HOWLADAR, S. M. Common bean (Phaseolus vulgaris L.) seedlings overcome $\mathrm{NaCl}$ stress as a result of presoaking in Moringa oleifera leaf extract. Scientia Horticulturae, v. 162, n. 1, p. 63-70, 2013.

RODRIGUES, C. R. F. et al. Physiological adjustment to salt stress in $R$. communis seedlings is associated with a probable mechanism of osmotic adjustment and a reduction in water lost by transpiration. Industrial Crops and Products, v. 54, n. 1, p. 233-239, 2014.

SACRAMENTO, B. L. et al. Pigmentos e teores de solutos orgânicos em plantas de aguapé sob estresse salino. Enciclopédia Biosfera, v. 10, n. 18, p. 33-44, 2014.

SCHOSSLER, T. R. et al. Salinidade: efeitos na fisiologia e na nutrição mineral de plantas. Enciclopédia Biosfera, v. 8, n. 15 , p. $1563-1578,2012$.

SHANNON, M. C.; GRIEVE, C. M. Tolerance of vegetable crops to salinity. Scientia Horticulturae, v. 78, n. 1, p. 5-38, 1999.

SILVEIRA, J. A. G. et al. Mecanismos biomoleculares envolvidos com a resistência ao estresse salino em plantas. In: GHEYI, H. R.; DIAS, N. S.; LACERDA, C. F. Manejo da salinidade na agricultura: estudos básicos e aplicados. Fortaleza: Instituto Nacional de Ciência e Tecnologia em Salinidade, 2010. p. 161-180.

SINGH, D. P.; SARKAR, R. K. Distinction and characterization of salinity tolerant and sensitive rice cultivars as probed by the chlorophyll fluorescence characteristics and growth parameters. Functional Plant Biology, v. 41, n. 7, p. 727-736, 2014.

SLAMA, I. et al. Diversity, distribution and roles of osmoprotective compounds accumulated in halophytes under abiotic stress. Annals of Botany, v. 115, n. 1, p. 433447, 2015.

SPEHAR, C. R. Diferenças morfológicas entre Amaranthus cruentus, cv. BRS Alegria, e as plantas daninhas A. hybridus, $A$. retroflexus, $A$. viridis e $A$. spinosus. Planta Daninha, v. 21, n. 3, p. 481-485, 2003.

TAIZ, L.; ZEIGER, E. Fisiologia vegetal. 5. ed. Porto Alegre: Artmed, 2013.

USA. National Research Council. Lost crops of the incas: little know plants of the Andes with promise for worldwide cultivation. Washington, DC: National Academy Press, 1989.

YEMM, E. W.; COCKING, E. C. The determination of amino-acids with ninhydrin. Analytical Chemistry, v. 80, n. 1, p. $209-213,1955$ 